\title{
Proposed definition of 'poor mobilizer' in lymphoma and multiple myeloma: an analytic hierarchy process by ad hoc working group Gruppo ItalianoTrapianto di Midollo Osseo
}

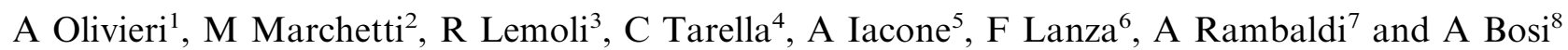 \\ on behalf of the Italian Group for Stem Cell Transplantation (GITMO) \\ ${ }^{1}$ Unità Operativa di Ematologia e Trapianto di Cellule Staminali, Ospedale San Carlo, Potenza, Italy; ${ }^{2}$ Hematology Unit, Ospedale \\ Cardinal Massaia, Asti, Italy; ${ }^{3}$ Department of Hematology and Oncological Sciences 'L \& A Seràgnoli', University of Bologna, \\ Bologna, Italy; ${ }^{4}$ Hematology and Cell Therapy Unit, AO O Mauriziano and Molecular Biotechnology Center, University of Torino, \\ Torino, Italy; ${ }^{5}$ Transfusion Medicine Department, Ospedale dello Spirito Santo Pescara, Pescara, Italy; ${ }^{6}$ Department of Hematology, \\ Cremona Hospital, Cremona, Italy; ${ }^{7}$ Alessandro Rambaldi, Hematology-Oncology, Ospedali Riuniti di Bergamo, Bergamo, Italy and \\ ${ }^{8}$ Department of Hematology Alberto Bosi, Firenze, Italy
}

Many lymphoma and myeloma patients fail to undergo ASCT owing to poor mobilization. Identification of poor mobilizers (PMs) would provide a tool for early intervention with new mobilization agents. The Gruppo italianoTrapianto di Midollo Osseo working group proposed a definition of PMs applicable to clinical trials and clinical practice. The analytic hierarchy process, a method for group decision making, was used in setting prioritized criteria. Lymphoma or myeloma patients were defined as 'proven PM' when: (1) after adequate mobilization (G-CSF $10 \mu \mathrm{g} / \mathrm{kg}$ if used alone or $\geqslant 5 \mu \mathrm{g} / \mathrm{kg}$ after chemotherapy) circulating $\mathrm{CD} 34^{+}$cell peak is $<20 / \mu \mathrm{L}$ up to 6 days after mobilization with G-CSF or up to 20 days after chemotherapy and G-CSF or (2) they yielded $<2.0 \times 10^{6} \mathrm{CD34}^{+}$cells per $\mathrm{kg}$ in $\leqslant 3$ apheresis. Patients were defined as predicted PMs if: (1) they failed a previous collection attempt (not otherwise specified); (2) they previously received extensive radiotherapy or full courses of therapy affecting SC mobilization; and (3) they met two of the following criteria: advanced disease $(\geqslant 2$ lines of chemotherapy), refractory disease, extensive BM involvement or cellularity $<30 \%$ at the time of mobilization; age $\geqslant 65$ years. This definition of proven and predicted PMs should be validated in clinical trials and common clinical practice.

Bone Marrow Transplantation (2012) 47, 342-351; doi:10.1038/bmt.2011.82; published online 30 May 2011 Keywords: stem cell mobilization; autologous transplantation; consensus conference; lymphoma; multiple myeloma

Correspondence: Dr A Olivieri, Unità Operativa di Ematologia e Trapianto di Cellule Staminali, Ospedale San Carlo, Via Potito Petrone 1, Potenza 85100, Italy.

E-mail: attilio.olivieri@ospedalesancarlo.it

Received 23 September 2010; revised 18 January 2011; accepted 8 March 2011; published online 30 May 2011
Introduction

ASCT of PBSCs is the first option for patients with relapsed lymphoma or multiple myeloma (MM). ${ }^{1-8}$ Successful engraftment correlates with the number of CD $34^{+}$ hemopoietic progenitors cells infused; ${ }^{9-12}$ however, a proportion of MM or lymphoma patients fail to mobilize PBSCs and cannot proceed to ASCT. ${ }^{12-18}$

The definition of 'poor' mobilization varies, owing to the different parameters set to evaluate the extent of mobilization: peak of $\mathrm{CD}_{3} 4^{+}$cells in $\mathrm{PB}$, cumulative apheresis yield or simply percent of candidate patients undergoing ASCT. Various criteria have been proposed to define a successful $\mathrm{CD} 4^{+}$cell mobilization and the adequate apheresis yield, but these data are difficult to analyse and compare with each other. ${ }^{10,12,15,19,20}$ Therefore, a systematic review of the literature does not provide a clear definition of poor mobilization.

Standardization of criteria for diagnosis, prognosis and response is a major goal of the haematology community and may facilitate comparison among retrospective and prospective data. For these reasons, Gruppo italianoTrapianto di Midollo Osseo GITMO (Italian Group for Stem Cell Transplantation) convened a Working Group (WG) to clarify the definition of 'poor mobilizer' (PM). This is essential for the assessment of PBSCs' mobilization in clinical trials and as a decision criterion for streamlining mobilization strategies in clinical practice. To develop the criteria for the definition of the PM, GITMO-WG adopted a flexible decision-making method: the analytic hierarchy process (AHP) was developed to establish priorities and make the best decision when both the quantitative and qualitative aspects of a decision needed to be considered and a poor information base was available. ${ }^{21}$ AHP is a multistep process, including four major phases: (1) defining the goal; (2) decomposing the problem and identifying critical issues; (3) categorizing/framing the main criteria; and (4) defining a hierarchy of the criteria. The participants' subjective judgment allows them to overcome the 
scarcity or inconsistency of available information on the problem; finally, they are forced to quantify their subjective judgments by pairwise comparisons among the decided criteria. AHP has been successfully applied to develop the criteria of refractoriness, resistance or response in haematology. ${ }^{22,23}$ The final definition of PM developed by the GITMO-WG is reported here, along with details with regard to the AHP method employed for defining criteria for poor PBSC mobilization.

\section{Methods}

A GITMO-WG of seven experts, with specific expertise in the field of PBSCs' mobilization, harvest, CD34 ${ }^{+}$cell count and ASCT, was selected to develop a standard definition of patients with lymphoma or MM failing to mobilize adequate $\mathrm{CD} 4^{+}$cells to proceed to ASCT (referred to as PM).

English-language articles were extracted focusing clinical studies of PBSC mobilization in lymphoma or MM patients and particularly the studies aimed at defining the adequate dose of $\mathrm{CD} 4^{+}$cells for ASCT; AHP was used to identify the values and criteria that define poor mobilization. The participants first framed the conceptual criteria, and then the operational criteria: they are qualitative and quantitative, respectively. For instance, 'old age' is a conceptual criterion, whereas 'older than 65 years' is an operational criterion. Conceptual criteria were selected by the first questionnaire, if there was $>80 \%$ agreement among the participants. Rank of the core set criteria was assigned through a number from 1 to 9 and the geometric mean of the ranks was calculated. Framing of operational criteria was obtained through the second questionnaire and by consensus through the Nominal Group Technique. ${ }^{24}$ The participants set the hierarchy of the operational criteria by pairwise comparison. Each participant analysed 55 couples of operational criteria and assigned a relative weight of one criterion with respect to the other one: if the former criterion was judged to have a higher importance than the latter, a weight from 1 to 9 was indicated; if the former criterion was less important than the latter, a weight from $1 / 9$ to 1 was indicated. Inter-participant standardized geometric means of the weights for each criterion were calculated, and subsequently, inter-participant means were also calculated.

Finally, 36 scenarios were built by the combination of operational criteria: for each scenario, the participants were requested to check whether the definition of 'predicted PM' held. A representative scenario is: 'The patient is a predicted PM if he or she is older than 65 years and shows extensive BM involvement at mobilization'. Each scenario received approval by each participant. The percent agreement of each scenario was compared with the sum of weights (obtained by pairwise comparison) of the criteria composing the scenario itself, and plotted. ${ }^{21}$

\section{Results}

The GITMO-WG agreed that establishing a clear definition of PM would help to optimize mobilization and transplant strategies (Figure 1); this might eventually reduce the need for: (1) repeated mobilization procedures; (2) SC harvest from $\mathrm{BM}$; and (3) switch to allogeneic transplantation or other strategies.

\section{Decomposition of the problem}

GITMO-WG deemed that the issue of 'poor mobilization' may pertain to three sequential phases:

(i) before the mobilizing treatment, when the mobilization procedure is planned;

(ii) during the mobilization procedure; and

(iii) at the completion of the whole PBSCs collection process.

The criteria supporting a prediction of 'poor mobilization' in the first phase may help one to identify patients at 'high risk' of 'poor mobilization' (predicted PM) and cannot be amended because they pertain to a patient's history, age or disease status. The criteria supporting a judgment of 'poor mobilization' during the second phase are markers of the biological capability of the patient to mobilize SC. They are dynamic and subject to change while mobilization is ongoing (for example, increase in the dose of G-CSF or addition of a new drug). The third phase involves both the host (history and mobilization ability) and the performance of the apheresis procedure (apheresis volumes, timing of collections, efficiency, and so on). Keeping in mind an operational definition of poor mobilization, GITMO-WG agreed that the criteria for defining a 'proven PM' pertain both to the second and third phase. However, even if an adequate $\mathrm{CD} 34^{+}$cell peak after mobilization predicts a successful collection, it cannot be considered a sufficient condition for a good harvest, as the latter is dependent on correct timing and performance of the apheresis procedure.

\section{Framing of criteria}

Through the first questionnaire, the GITMO-WG analysed 33 candidate conceptual criteria (Table 1); among them two (nos. 2 and 7) were selected for 'proven PM' and 'proven poor mobilization' (PPM) and 10 for 'predicted PM' (nos. 14-19 and 21-24); these latter were reduced to eight as 'disease status' was split into 'advanced disease' and 'refractory disease'; 'previous therapy with lenalidomide'
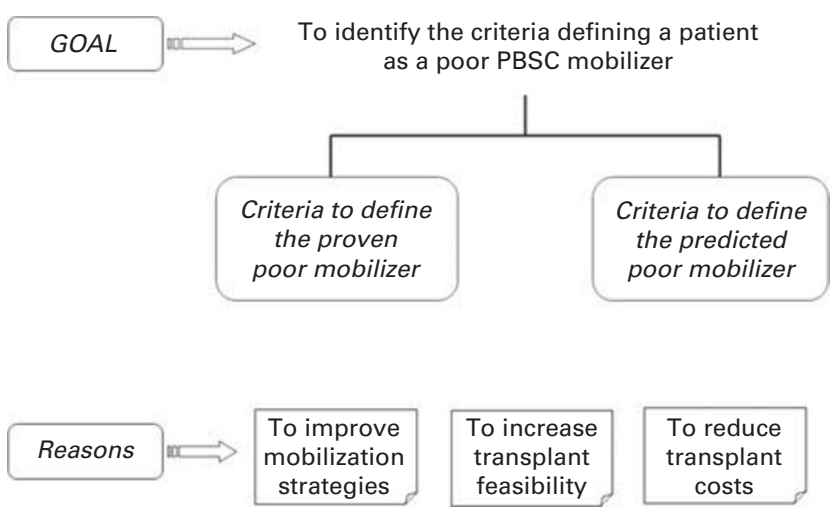

Figure 1 Goals and reasons of the GITMO-WG project. 
Table 1 Candidate conceptual criteria evaluated in the first questionnaire; the core set criteria selected after the first questionnaire are represented in italic bold characters

\begin{tabular}{|c|c|c|c|}
\hline & Conceptual criteria & $\begin{array}{l}\text { Percentage of } \\
\text { agreement }\end{array}$ & Main references \\
\hline 1 & Harvested CD34+ cells & 86 & $9,11,12,19,20,25-29$ \\
\hline 2 & Harvested CD34 ${ }^{+}$cells per planned SCT & 100 & \\
\hline 3 & No. of planned ASCT & 57 & \\
\hline 4 & Overall harvested CD $34^{+}$cells after two aphereses & 71 & $20,30,31,28$ \\
\hline 5 & Harvested CD34 + cells at first apheresis & 57 & \\
\hline 6 & Pre- and post-apheresis $\mathrm{CD}_{3} 4^{+}$cell count & 57 & $30-35$ \\
\hline 7 & Absolute number of circulating $\mathrm{CD}_{3} 4^{+}$cells per $\mu \mathrm{L}$ & 100 & \\
\hline 8 & Overall number of nucleated cells harvested & 14 & $26,35,36$ \\
\hline 9 & Overall number of nucleated cells harvested per planned SCT & 14 & \\
\hline 10 & Planned volumes of apheresis & 57 & $30,37-40$ \\
\hline 11 & Chemo-mobilization & 71 & $41-50$ \\
\hline 12 & Mobilizing G-CSF dose & 71 & \\
\hline 13 & Diagnosis of underlying disease & 71 & $49,50,51-67$ \\
\hline 14 & Age & 100 & \\
\hline 15 & Disease status & 100 & $9,10,12,14,52,56,59,60,68$ \\
\hline 16 & BM involvement & 86 & \\
\hline 17 & Pre-mobilization BM cellularity & 86 & \\
\hline 18 & No. of previous cytotoxic therapy lines & 100 & $17,18,52-55,59,62,63,69,70$ \\
\hline 19 & Duration of previous chemotherapy & 71 & \\
\hline 20 & Interval elapsed since previous chemotherapy & 29 & \\
\hline 21 & Previous extensive radiotherapy & 100 & $36,48,52,65,67,68,71,72$ \\
\hline 22 & Previous alkylating therapy & 86 & \\
\hline 23 & Previous therapy with lenalidomide & 86 & 73-76 \\
\hline 24 & Previous therapy with fludarabine & 86 & $77-82$ \\
\hline 25 & Platelet count at first apheresis & 29 & $12,14,15,17,30,33-35,38-40,49,56,50,83-86$ \\
\hline 26 & Time to platelet recovery after chemo-mobilization & 57 & \\
\hline 27 & Pre-mobilization WBC/Plt count & 14 & \\
\hline 28 & Circulating CD $34^{+}$cells in steady-state previous PBSC mobilization & 14 & \\
\hline 29 & Fold-increase of circulating $\mathrm{CD} 34^{+}$cells per $\mu \mathrm{L}$ with respect to baseline & 43 & $10,12,14,15,19,20,30-35,83,84,87,88$ \\
\hline 30 & $\begin{array}{l}\text { Absolute number of circulating } \mathrm{CD} 34^{+} \text {cells per } \mu \mathrm{L} \text { at a predetermined } \\
\text { timing after the start of mobilization }\end{array}$ & 86 & \\
\hline 31 & Kinetics of mobilization of $\mathrm{CD} 34^{+}$cells & 43 & \\
\hline 32 & Time to reach the $\mathrm{CD} 34^{+}$cell peak & 57 & \\
\hline 33 & Kinetics of mobilization of MNC cells & 43 & \\
\hline
\end{tabular}

Abbreviation: $\mathrm{MNC}=$ multinucleate cells.

and 'previous therapy with fludarabine' were included in the same category, and the new criteria 'previous exposure to other therapies potentially affecting SC mobilization' include criteria numbers $18,19,22$. The reasons for excluding the remaining criteria included characteristics of the mobilization strategy (nos. 10-12), redundancy, scarce clinical application or poor predictive value (that is, mononuclear cell count). As for the mobilization strategy, GITMO-WG deemed it necessary to include the optimal dose of G-CSF in the definition of PM: G-CSF dose $\geqslant 10 \mu \mathrm{g} / \mathrm{kg}$ if used alone or $\geqslant 5 \mu \mathrm{g} / \mathrm{kg}$ after mobilizing chemotherapy. Through a second questionnaire, GITMOWG ranked the 10 conceptual criteria from the core set and chose among 2-4 operational definitions for each conceptual criterion (Table 2). Among predicting criteria, a high rank was assigned to previous extensive radiotherapy and exposure to drugs known to affect the mobilization capacity. The operational definitions of the two criteria for the proven $\mathrm{PM}\left(\mathrm{CD} 34^{+}\right.$cells peak in $\left.\mathrm{PB}\right)$ and PPM (the final $\mathrm{CD} 34^{+}$cell harvest) were scored and discussed by Nominal Group Technique. ${ }^{24}$ As both the criteria concurred to the definition, harmonization of their operational wording was requested. Moreover, GITMO-WG established that the cutoff of $\geqslant 2.0 \times 10^{6} \mathrm{CD}^{2} 4^{+}$cells per $\mathrm{kg}$ harvested must be integrated with a pre-fixed number of apheresis procedures performed: $\leqslant 3$ apheresis days within a single mobilization attempt, after G-CSF alone or after chemo-mobilization. Finally, the peak of PB $\mathrm{CD}^{+} 4^{+}$cells was timed according to the mobilization strategy adopted, as a larger variability in $\mathrm{PB} \mathrm{CD} 34^{+}$ kinetics is expected after chemo-mobilization. Operational criteria for defining 'predicted $\mathrm{PM}$ ' require some adjustments about the age cutoff and BM cellularity; there was major disagreement with regard to exposure to drugs or therapies potentially affecting SC mobilization, as a larger body of evidence supports a detrimental effect of selected alkylating drugs, that is, melphalan and fludarabine, whereas fewer reports were published on the detrimental effect of lenalidomide. Finally, GITMO-WG expressed the requirement to consider only full-course therapies damaging SC mobilization, as lower doses or shorter therapies are not ascertained detrimental factors.

\section{Hierarchy of the operational criteria}

The GITMO-WG compared the 10 operational criteria by pairs and elaborated the relative importance weight of one criterion to another (Table 2). Pairwise comparison of the 
Table 2

Relative importance of the selected core set criteria, expressed both as conceptual and by operational definitions

\begin{tabular}{|c|c|c|c|c|}
\hline Conceptual criteria & Operational criteria & $\begin{array}{l}\text { Rank } \\
(1-9)\end{array}$ & $\begin{array}{l}\text { Pairwise } \\
\text { comparison }\end{array}$ & $\begin{array}{l}\text { Variability } \\
\quad(\%)\end{array}$ \\
\hline Harvested CD34 ${ }^{+}$cells & $\begin{array}{l}\text { Less than } 2.0 \times 10^{6} \text { harvested } \mathrm{CD} 34^{+} \text {cells per } \mathrm{kg} \text { per planned } \\
\text { SCT by no more than three aphereses }\end{array}$ & 8.7 & 0.26 & 47 \\
\hline Peak of $\mathrm{CD}_{3} 4^{+}$cells & $\begin{array}{l}\text { Peak CD } 34^{+} \text {cell count }<20 / \mu \mathrm{L} \text { on days } 4-6 \text { after the start of mobilization } \\
\text { with G-CSF alone or up to } 18-20 \text { days after chemotherapy and G-CSF }\end{array}$ & 8.0 & 0.25 & 36 \\
\hline Refractory disease & & 6.0 & 0.08 & 74 \\
\hline Advanced disease & Advanced disease, that is, at least two previous cytotoxic lines & 5.8 & 0.12 & 38 \\
\hline Extensive radiotherapy & Extensive radiotherapy to marrow bearing tissue & 7.2 & 0.08 & 54 \\
\hline $\begin{array}{l}\text { Previous exposure to fludarabine, } \\
\text { melphalan, lenalidomide }\end{array}$ & & 6.6 & 0.06 & 47 \\
\hline $\begin{array}{l}\text { Previous exposure to other therapies } \\
\text { potentially affecting SC } \\
\text { mobilization }\end{array}$ & & 4.8 & 0.03 & 67 \\
\hline $\begin{array}{l}\text { Extensive BM involvement at } \\
\text { mobilization }\end{array}$ & & 5.4 & 0.04 & 47 \\
\hline $\begin{array}{l}\text { Poor BM cellularity at } \\
\text { mobilization }\end{array}$ & BM cellularity $<30 \%$ at mobilization & 4.8 & 0.04 & 42 \\
\hline Old age & Age older than 65 years & 5.1 & 0.02 & 50 \\
\hline
\end{tabular}

Although the $\mathrm{CD}_{3} 4^{+}$cell count reflects the biological mobilization ability, whereas the $\mathrm{CD}^{+} 4^{+}$cell harvest in a pre-fixed number of apheresis days defines a poor mobilization, the terms of poor mobilizer and poor mobilization have been pragmatically considered equivalent. Inter-participant geometric means are reported. Inter-participants' variability of pairwise comparison is also reported in the fourth column.

two criteria defining 'proven PM' and PPM (harvested $\mathrm{CD}^{+}{ }^{+}$cells and peak CD34 ${ }^{+}$cells) showed two similar scores, thus confirming similar ranks. Indeed, GITMO-WG considered each of the two criteria itself sufficient to sustain a judgment of 'predicted PM', but recognized that a poor harvest may be caused by technical problems affecting the extraction efficiency and the final yield of circulating $\mathrm{CD} 4^{+}$cells. These problems may consist of delayed or anticipated timing of apheresis, small volume of processed blood and any troubles during the procedure that may prejudice the harvesting, even though the patient achieved a satisfactory peak of $\mathrm{CD} 34^{+}$cells in PB. Pairwise comparison was particularly important to rank the importance of the eight criteria for defining 'predicted PM'. Advanced disease, refractory disease and previous extensive radiotherapy were the three criteria that decidedly had a higher importance. However, GITMO-WG observed that the criteria were biologically and clinically dependent on the others and, therefore, covariate.

A third questionnaire was finally completed including 36 scenarios combining the above eight criteria (Figure 2) and identified previous extensive radiotherapy as the most powerful independent criterion. The scenarios also identified previous exposure to therapies potentially affecting SC mobilization as synergic independent factors, whereas disease status itself was not sufficient to fulfil the definition of 'predicted PM'. Therefore, the panel decided to join two conceptual criteria into a unique exhaustive one, which included therapies definitely proven to affect mobilization and all the other therapies that have been or will be proven to negatively affect SC mobilization. Finally, GITMO-WG decided to extend the definition of predicted 'PM' to those patients with a history of failure, not otherwise specified, and listed an additional specific criterion. On the basis of the above information, GITMO-WG separated the criteria for defining 'predicted PM' into two categories: major and minor. The former category included the three most powerful criteria, which are: previous failed mobilization,

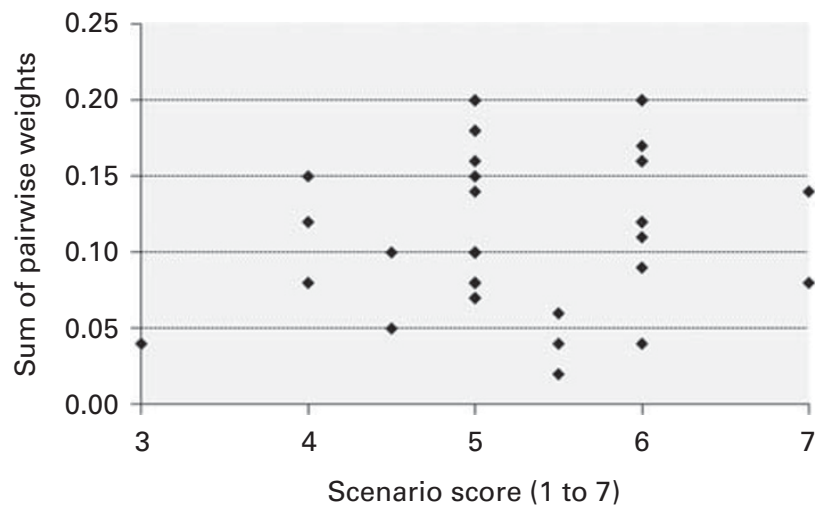

Figure 2 Scoring of 36 scenarios by sum of pairwise weights of direct judgment after the third questionnaire evaluation; all the scenarios have been framed by combining different operational definitions, generated from the selected conceptual criteria. The best scored scenarios concurred to the final definition of proven and predicted poor mobilizer.

not otherwise specified, previous extensive radiotherapy and previous therapies detrimental to SC mobilization. The second category included: advanced phase disease, refractory disease, extensive BM involvement, BM cellularity $<30 \%$ (before mobilization) and age $>65$ years. Although one major criterion was sufficient to qualify a patient as 'predicted PM', the presence of at least two minor criteria was requested to qualify a patient as 'predicted PM' (Table 3).

\section{Discussion}

In this paper, GITMO-WG applied the AHP methods to select the operational criteria useful to identify the PM in current medical practice; at least $15 \%$ of lymphoma or MM patients fail to produce the target cell dose of $\geqslant 2 \times 10^{6} /$

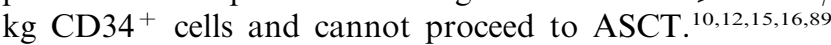


Table 3 Final definitions of proven and predicted poor mobilizer

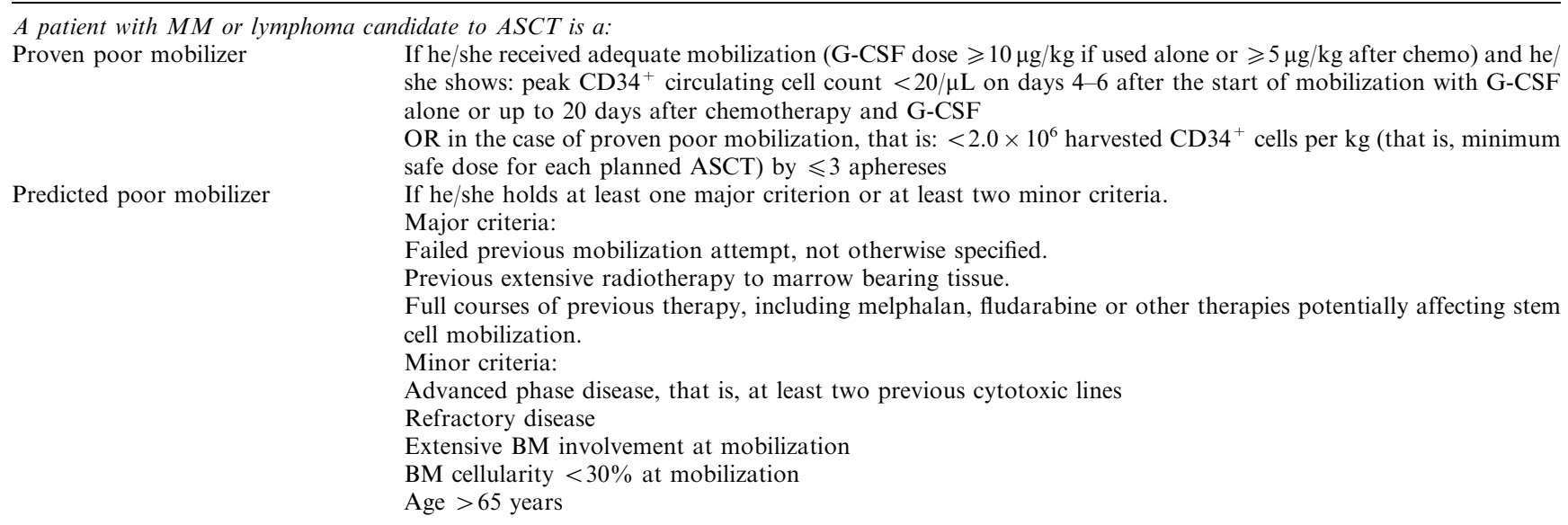

Re-infusion of high doses of $\mathrm{CD}_{3} 4^{+}$cells is associated with fast platelet and neutrophil engraftment, leading to a significant cost sparing $25,26,51,90-94$ and increased survival rates. ${ }^{52,95-100}$ GITMO-WG selected two conceptual criteria to identify proven PM and/or PPM: (I) peak of CD34 ${ }^{+}$ cells in PB and (II) harvested CD34 ${ }^{+}$cells.

The WG agreed about the definition of PM also for those patients who did not achieve at least $2.0 \times 10^{6} \mathrm{CD}^{4} 4^{+}$ during 3 apheresis days. Previous reports on the remobilization in this setting show that only a minority of patients was able to achieve the $2.0 \times 10^{6} \mathrm{CD} 34^{+}$threshold after a second mobilization attempt; ${ }^{12,15}$ in particular, Pusic et al. ${ }^{16}$ reports that among 269 patients remobilized, only $62(23 \%)$ yielded $\geqslant 2.0 \times 10^{6} \mathrm{CD}^{+} 4^{+}$.

In the past, the quality of PB harvest has been evaluated both as CFU-GM and as $\mathrm{CD}^{+} 4^{+}$cell content, whereas limited data suggest a relationship between mononuclear cell count and $\mathrm{CD}^{+} 4^{+}$cell content in mobilized $\mathrm{PB} .{ }^{27,32}$ Despite persistence of controversies about the most reliable technique for enumerating the $\mathrm{CD} 34^{+}$cell content both in PB and in the harvest, ${ }^{101-103}$ GITMO-WG agreed that preapheresis $\mathrm{CD}_{3} 4^{+}$cell count in $\mathrm{PB}$ is the best predictor of $\mathrm{CD} 4^{+}$cells in the apheresis products ${ }^{12,16,30,31,33-35,83,84}$ and pragmatically considered a peak of CD34 ${ }^{+}$cells $>20 \mu \mathrm{L}$ in $\mathrm{PB}$, as a reliable indicator of a satisfactory mobilization ability; on the other hand, the strong correlation between the pre-apheresis $\mathrm{CD}_{3} 4^{+}$cell count and the final harvest also indicates that a PPM could be considered a reliable marker of a proven PM. ${ }^{12,16,30,31,33-35,83,84}$

The GITMO-WG agreed on $2.0 \times 10^{6} \mathrm{CD} 34^{+}$cells per $\mathrm{kg}$ as the minimum safe dose for ensuring rapid neutrophil and platelet recovery both in lymphoma and in MM patients; ${ }^{10-12,16,25,26,93,94}$ others suggested a different dose, such as 2.5 (refs. 9,11,26,28,29,104) or $1.5 \times 10^{6} \mathrm{CD}^{+} 4^{+}$ cells per $\mathrm{kg},{ }^{105}$ but below $1 \times 10^{6} / \mathrm{kg} \mathrm{CD} 34^{+}$cells, a high risk of delayed platelet recovery has been reported. ${ }^{28}$

GITMO-WG reviewed the current mobilization strategies as they can influence the SC mobilization, but cannot be considered the criteria for the definition of PM. When $\mathrm{G}-\mathrm{CSF}$ alone is used, it is administered at doses ranging from 10 to $16 \mu \mathrm{g} / \mathrm{kg}$ daily; ${ }^{10}$ higher doses resulted in better harvest, ${ }^{106-108}$ not confirmed in subsequent experiences, ${ }^{109}$ as well the combination of G-CSF plus GM-CSF. ${ }^{110,41,42}$
After the demonstration of the synergistic effect of $\mathrm{CY}$ and GM-CSF ${ }^{111}$ G-CSF followed by chemotherapy has been reported to mobilize similar number of $\mathrm{CD} 34^{+}$cells; ${ }^{42-44}$ therefore, as this cytokine has a better safety profile, at present the mobilization with $\mathrm{CY}$ and G-CSF at $5 \mu \mathrm{g} / \mathrm{kg}$ is widespread. ${ }^{44} \mathrm{~A}$ randomized study comparing different doses of G-CSF after chemotherapy did not show substantial benefit with higher doses. ${ }^{45}$ The use of diseaseoriented chemo-mobilization in the context of a welldesigned treatment ${ }^{98,112-114}$ resulted in better harvest compared with G-CSF alone, ${ }^{10,16}$ but this did not translate into a better clinical outcome. ${ }^{46,47}$ As regards these two mobilization strategies, GITMO-WG deemed that the same criteria for identifying the PM should be employed, even if the different timing of $\mathrm{CD} 34^{+}$cell peaks and the different doses of G-CSF must be taken in account. GITMO-WG excluded from definition of PMs those patients who cannot reach a $\mathrm{CD}_{3} 4^{+}$cell peak $\geqslant 20 / \mu \mathrm{L}$, but who were equally able to achieve the target CD34 ${ }^{+}$cell dose by means of $\leqslant 3$ large-volume aphereses. ${ }^{37}$

As the identification of the 'predicted PM' GITMO-WG defined three major and five minor criteria, the most important criteria were as follows: previous cytotoxic chemotherapy and irradiation. The average decrease estimated for each cycle of chemotherapy is of $0.2 \times 10^{6}$

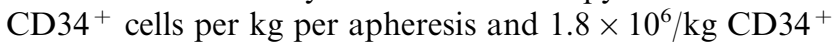
cells after large-field radiotherapy, whereas a local irradiation is not associated with impaired mobilization. ${ }^{36,48,68,69,71}$ Although underlying disease has been reported as a factor influencing mobilization, ${ }^{49,53-56}$ GITMO-WG deemed that this is not an independent factor, being influenced by the previous treatment and by the disease status. Advanced disease is often associated with extensive BM involvement. In addition, in lymphoma patients BM involvement and platelet count before mobilization are associated with mobilization failure, ${ }^{9,10,36,57-62}$ and although it was difficult to identify a clear age cutoff, ${ }^{63,64}$ GITMO-WG deemed that older age is an important factor associated with poor mobilization. ${ }^{65,50,66}$

GITMO-WG agreed that the higher percentage of PM is characterized by either morphological or functional injury to BM, caused by extensive radiotherapy or/and chemotherapy, but also by the so-called stem cell poisons. ${ }^{36}$ 
This heterogeneous group of drugs includes purine analogues, melphalan, ${ }^{67,72}$ and the list has recently included thalidomide $^{115}$ and lenalidomide. ${ }^{73-76}$ Fludarabine negatively affects mobilization in patients with CLL; ${ }^{77-80}$ however, some authors reported satisfactory collections, ${ }^{81}$ whereas others recommend paying attention to the interval from last dose of fludarabine. ${ }^{82}$

Among the other factors associated with unsuccessful mobilization, including PB white cell count, platelet count, apheresis techniques, interval between last chemotherapy and mobilization attempt, ${ }^{9,34,38-40,61,69,70,85-88,116,117}$ the platelet counts before mobilization seem a reliable indicator of adequate marrow function, but this factor has not been considered sufficiently powerful like the ones selected as conceptual criteria.

In conclusion, poor mobilization of $\mathrm{SC}$ is a major limitation to ASCT in lymphoma and MM, and the availability of new drugs, able to increase the SC mobilization, requires a stringent definition of the PM. Several patient- and disease-related factors have been retrospectively identified, but never prospectively validated. GITMO-WG recommend that patients previously failing at least one mobilization attempt should be candidates for new mobilizing strategies. ${ }^{19,20,118}$ Excluding this selected group, the preventive identification of PM, by using the criteria established here, should be validated in a prospective trial. In the meantime, the GITMO-WG recommend using standard criteria for identifying both the "proven and the predicted PM' before planning the use of new mobilizing agents. Recently, two large series of patients with lymphoma or MM have been retrospectively evaluated define PM, according to the standardized criteria: extensive previous chemotherapy, previous melphalan exposure and a previous failed mobilization attempt have been identified as predictive factors of poor mobilization. Pusic et al. ${ }^{16}$ reports that $19 \%$ of patients yielding $<2 \times 10^{6} \mathrm{CD}^{+} 4^{+}$cells per $\mathrm{kg}$ during five apheresis after mobilization with G-CSF alone, ${ }^{16}$ whereas Wuchter et al. ${ }^{12}$ identified $15 \%$ of PMs by using the criterion of a peak concentration $20 / \mu \mathrm{L}$ of $\mathrm{CD}^{+} 4^{+}$cells, after chemotherapy followed by G-CSF. ${ }^{12}$ The International Myeloma Working Group also proposed some qualitative predictive risk factors for poor mobilization, without any ranking. ${ }^{119}$ The GITMO-WG worked to define simple, but stringent operational criteria for the identification/prediction of the PM in the setting of $\mathrm{MM}$ and lymphoma patients. The decision to separate the criteria for defining 'predicted PM' into two categories (major and minor) could be questionable, but it keeps the advantage to be easy to use and to update. Recently, new mobilizing agents, such as plerixafor, proved to be effective in PM. ${ }^{118,120,121}$ However, the scientific community has not still provided a standard definition of PM, who may potentially benefit from this drug; therefore, these criteria could help the selection of those patients who could benefit from new mobilizing drugs, waiting for a definitive validation by a prospective trial.

\section{Conflict of interest}

This paper has been completed after three Expert Meetings supported by Genzyme Corporation. The authors received a reimbursement and an honorarium. The authors declare that there are no competing financial interests in relation to this work.

\section{References}

1 Dreyling M, Hiddemann W. Current treatment standards and emerging strategies in mantle cell lymphoma. Hematol Am Soc Hematol Educ Program 2009, 542-551.

2 Foster M, Gabriel DA, Shea T. Role of hematopoietic stem cell transplant in the management of follicular lymphoma. Oncologist 2009; 14: 726-738.

3 Harousseau J, Attal M. The role of autologous hematopoietic stem cell transplantation in multiple myeloma. Semin Hematol 1997; 34(Suppl 1): 61-66.

4 Hernandez-Ilizaliturri FJ, Czuczman MS. Therapeutic options in relapsed or refractory diffuse large B-cell lymphoma. Part 2. Novel therapeutic strategies. Oncology (Williston Park) 2009; 23: 610-615.

5 Moskowitz AJ, Moskowitz $\mathrm{CH}$. Controversies in the treatment of lymphoma with autologous transplantation. Oncologist 2009; 14: 921-929.

6 San-Miguel JF, Mateos MV. How to treat a newly diagnosed young patient with multiple myeloma. Hematol Am Soc Hematol Educ Program 2009, 555-565.

7 Thomas S, Alexanian R. Current treatment strategies for multiple myeloma. Clin Lymph Myeloma 2007; 7(Suppl 4): S139-S144.

8 Younes A. Novel treatment strategies for patients with relapsed classical Hodgkin lymphoma. Hematol Am Soc Hematol Educ Program 2009, 507-519.

9 Bensinger W, Appelbaum F, Rowley S, Storb R, Sanders J, Lilleby $\mathrm{K}$ et al. Factors that influence collection and engraftment of autologous peripheral-blood stem cells. J Clin Oncol 1995; 13: 2547-2555.

10 Bensinger W, DiPersio JF, McCarty JM. Improving stem cell mobilization strategies: future directions. Bone Marrow Transplant 2009; 43: 181-195.

11 Weaver C, Hazelton B, Birch R, Palmer P, Allen C, Schwartzberg L et al. An analysis of engraftment kinetics as a function of the CD34 content of peripheral blood progenitor cell collections in 692 patients after the administration of myeloablative chemotherapy. Blood 1995; 86: 3961-3969.

12 Wuchter P, Ran D, Bruckner T, Schmitt T, Witzens-Harig M, Neben $\mathrm{K}$ et al. Poor mobilization of hematopoietic stem cellsdefinitions, incidence, risk factors, and impact on outcome of autologous transplantation. Biol Blood Marrow Transplant 2010; 16: 490-499.

13 Hosing C, Saliba RM, Ahlawat S, Korbling M, Kebriaei P, Alousi A et al. Poor hematopoietic stem cell mobilizers: a single institution study of incidence and risk factors in patients with recurrent or relapsed lymphoma. Am J Hematol 2009; 84: 335-337.

14 Ameen RM, Alshemmari SH, Alqallaf D. Factors associated with successful mobilization of progenitor hematopoietic stem cells among patients with lymphoid malignancies. Clin Lymph Myeloma 2008; 8: 106-110.

15 Perseghin P, Terruzzi E, Dassi M, Baldini V, Parma M, Coluccia $\mathrm{P}$ et al. Management of poor peripheral blood stem cell mobilization: incidence, predictive factors, alternative strategies and outcome. A retrospective analysis on 2177 patients from three major Italian institutions. Transfus Apher Sci 2009; 41: 33-37.

16 Pusic I, Jiang SY, Landua S, Uy GL, Rettig MP, Cashen AF et al. Impact of mobilization and remobilization strategies on 
achieving sufficient stem cell yields for autologous transplantation. Biol Blood Marrow Transplant 2008; 14: 1045-1056.

17 Sugrue MW, Williams K, Pollock BH, Khan S, Peracha S, Wingard JR et al. Characterization and outcome of 'hard to mobilize' lymphoma patients undergoing autologous stem cell transplantation. Leuk Lymphoma 2000; 39 509-519.

18 Tarella C, Di Nicola M, Caracciolo D, Zallio F, Cuttica A, Omede $\mathrm{P}$ et al. High-dose ara-C with autologous peripheral blood progenitor cell support induces a marked progenitor cell mobilization: an indication for patients at risk for low mobilization. Bone Marrow Transplant 2002; 30: 725-732.

19 DiPersio JF, Micallef IN, Stiff PJ, Bolwell BJ, Maziarz RT, Jacobsen E et al. Phase III prospective randomized doubleblind placebo-controlled trial of plerixafor plus granulocyte colony-stimulating factor compared with placebo plus granulocyte colony-stimulating factor for autologous stem-cell mobilization and transplantation for patients with nonHodgkin's lymphoma. J Clin Oncol 2009; 27: 4767-4773.

20 DiPersio JF, Stadtmauer EA, Nademanee A, Micallef IN, Stiff PJ, Kaufman JL et al. Plerixafor and G-CSF versus placebo and G-CSF to mobilize hematopoietic stem cells for autologous stem cell transplantation in patients with multiple myeloma. Blood 2009; 113: 5720-5726.

21 Saaty $\mathrm{T}$. The analytic hierarchy process: scenarios, priorities and cost/benefits for the Sudan Transport Plan Operational Research '81. Proceedings of the Ninth IFORS International Conference: 1981. North-Holland: Hamburg, West Germany, 1981, 161-175.

22 Barosi G, Besses C, Birgegard G, Briere J, Cervantes F, Finazzi $\mathrm{G}$ et al. A unified definition of clinical resistance/ intolerance to hydroxyurea in essential thrombocythemia: results of a consensus process by an international working group. Leukemia 2007; 21: 277-280.

23 Barosi G, Birgegard G, Finazzi G, Griesshammer M, Harrison C, Hasselbalch $\mathrm{HC}$ et al. Response criteria for essential thrombocythemia and polycythemia vera: result of a European LeukemiaNet consensus conference. Blood 2009; 113: 4829-4833.

24 Jones J, Hunter D. Consensus methods for medical and health services research. BMJ 1995; 311: 376-380.

25 Jillella AP, Ustun C. What is the optimum number of CD34+ peripheral blood stem cells for an autologous transplant? Stem Cells Dev 2004; 13: 598-606.

26 Olivieri A, Offidani M, Montanari M, Ciniero L, Cantori I, Ombrosi L et al. Factors affecting hemopoietic recovery after high-dose therapy and autologous peripheral blood progenitor cell transplantation: a single center experience. Haematologica 1998; 83: 329-337.

27 Bender JG, To LB, Williams S, Schwartzberg LS. Defining a therapeutic dose of peripheral blood stem cells. J Hematother 1992; 1: 329-341.

28 Watts MJ, Sullivan AM, Jamieson E, Pearce R, Fielding A, Devereux S et al. Progenitor-cell mobilization after low-dose cyclophosphamide and granulocyte colony-stimulating factor: an analysis of progenitor-cell quantity and quality and factors predicting for these parameters in 101 pretreated patients with malignant lymphoma. J Clin Oncol 1997; 15: 535-546.

29 van der Wall E, Richel DJ, Holtkamp MJ, Slaper-Cortenbach $\mathrm{IC}$, van der Schoot CE, Dalesio $\mathrm{O}$ et al. Bone marrow reconstitution after high-dose chemotherapy and autologous peripheral blood progenitor cell transplantation: effect of graft size. Ann Oncol 1994; 5: 795-802.

30 Pettengell R, Morgenstern GR, Woll PJ, Chang J, Rowlands $\mathrm{M}$, Young $\mathrm{R}$ et al. Peripheral blood progenitor cell transplantation in lymphoma and leukemia using a single apheresis. Blood 1993; 82: 3770-3777.

31 Demirer T, Ilhan O, Ayli M, Arat M, Dagli M, Ozcan M et al. Monitoring of peripheral blood CD34+ cell counts on the first day of apheresis is highly predictive for efficient CD34 + cell yield. Ther Apher 2002; 6: 384-389.

32 Olivieri A, Offidani M, Ciniero L, Poloni A, Masia MC, Salvi A et al. Optimization of the yield of PBSC for autotransplantation mobilized by high-dose chemotherapy and G-CSF: proposal for a mathematical model. Bone Marrow Transplant 1994; 14: 273-278.

33 Schots R, Van Riet I, Damiaens S, Flament J, Lacor P, Staelens Y, Steenssens L, van Camp B, De Waele M. The: absolute number of circulating $\mathrm{CD} 34+$ cells predicts the number of hematopoietic stem cells that can be collected by apheresis. Bone Marrow Transplant 1996; 17: 509-515.

34 Fu P, Bagai RK, Meyerson H, Kane D, Fox RM, Creger RJ et al. Pre-mobilization therapy blood CD34+ cell count predicts the likelihood of successful hematopoietic stem cell mobilization. Bone Marrow Transplant 2006; 38: 189-196.

$35 \mathrm{Yu}$ J, Leisenring W, Bensinger WI, Holmberg LA, Rowley SD. The predictive value of white cell or CD34 + cell count in the peripheral blood for timing apheresis and maximizing yield. Transfusion 1999; 39: 442-450.

36 Dreger P, Klöss M, Petersen B, Haferlach T, Löffler H, Loeffler M, Schmitz N. Autologous progenitor cell transplantation: prior exposure to stem cell-toxic drugs determines yield and engraftment of peripheral blood progenitor cell but not of bone marrow grafts. Blood 1995; 86: 3970-3978.

37 Abrahamsen JF, Stamnesfet S, Liseth K, Hervig T, Bruserud O. Large-volume leukapheresis yields more viable CD34+ cells and colony-forming units than normal-volume leukapheresis, especially in patients who mobilize low numbers of CD34 + cells. Transfusion 2005; 45: 248-253.

38 Majado MJ, Minguela A, González-García C, Salido E, Blanquer M, Funes $\mathrm{C}$ et al. Large-volume-apheresis facilitates autologous transplantation of hematopoietic progenitors in poor mobilizer patients. J Clin Apher 2009; 24: 12-17.

39 Husson B, Ravoet C, Dehon M, Wallef G, Hougardy N, Delannoy A. Predictive value of the steady-state peripheral blood progenitor cell (PBPC) counts for the yield of PBPC collected by leukapheresis after mobilization by granulocyte colony-stimulating factor (G-CSF) alone or chemotherapy and G-CSF. Blood 1996; 87: 3526-3528.

40 Zubair AC, Grant R, Wu W, Tun H, Rivera C, MorenoAspitia A et al. Platelet count is a sensitive predictor of autologous peripheral blood progenitor cell collection yield in previously treated plasma cell disease patients. Transfusion 2008; 48: 1106-1114.

41 Gazitt Y, Callander N, Freytes CO, Shaughnessy P, Liu Q, Tsai TW et al. Peripheral blood stem cell mobilization with cyclophosphamide in combination with G-CSF, GM-CSF, or sequential GM-CSF/G-CSF in non-Hodgkin's lymphoma patients: a randomized prospective study. J Hematother Stem Cell Res 2000; 9: 737-748.

42 Weaver $\mathrm{CH}$, Schulman KA, Buckner CD. Mobilization of peripheral blood stem cells following myelosuppressive chemotherapy: a randomized comparison of filgrastim, sargramostim, or sequential sargramostim and filgrastim. Bone Marrow Transplant 2001; 27(Suppl 2): S23-S29.

43 Arora M, Burns LJ, Barker JN, Miller JS, Defor TE, Olujohungbe $\mathrm{AB}$ et al. Randomized comparison of granulocyte colony-stimulating factor versus granulocyte-macrophage colony-stimulating factor plus intensive chemotherapy for peripheral blood stem cell mobilization and autologous transplantation in multiple myeloma. Biol Blood Marrow Transplant 2004; 10: 395-404. 
$44 \mathrm{Fu} \mathrm{S}$, Liesveld J. Mobilization of hematopoietic stem cells. Blood Rev 2000; 14: 205-218.

45 Demirer T, Ayli M, Ozcan M, Gunel N, Haznedar R, Dagli $\mathrm{M}$ et al. Mobilization of peripheral blood stem cells with chemotherapy and recombinant human granulocyte colony-stimulating factor (rhG-CSF): a randomized evaluation of different doses of rhG-CSF. Br J Haematol 2002; 116: 468-474.

46 Narayanasami U, Kanteti R, Morelli J, Klekar A, Al-Olama $\mathrm{A}$, Keating $\mathrm{C}$ et al. Randomized trial of filgrastim versus chemotherapy and filgrastim mobilization of hematopoietic progenitor cells for rescue in autologous transplantation. Blood 2001; 98: 2059-2064.

47 Koc ON, Gerson SL, Cooper BW, Laughlin M, Meyerson H, Kutteh L et al. Randomized cross-over trial of progenitor-cell mobilization: high-dose cyclophosphamide plus granulocyte colony-stimulating factor (G-CSF) versus granulocytemacrophage colony-stimulating factor plus G-CSF. $J$ Clin Oncol 2000; 18: 1824-1830.

48 Brugger W, Bross K, Frisch J, Dern P, Weber B, Mertelsmann $\mathrm{R}$ et al. Mobilization of peripheral blood progenitors by sequential administration of interleukin-3 and granulocyte-macrophage colony-stimulating factor following polychemotherapy with etoposide, ifosfamide and cisplatin. Blood 1992; 79: 1193-1200.

49 Zhang C, Chen X, Zhang X, Gao L, Kong P, Wang Q et al. Mobilization of peripheral blood stem cells for autologous transplantation patients with hematological malignancies: influence of disease, mobilization method, age and sex. Transfus Apher Sci 2008; 39: 21-28.

50 Hosing C, Saliba RM, Ahlawat S, Korbling M, Kebriaei P, Alousi A et al. Poor hematopoietic stem cell mobilizers: a single institution study of incidence and risk factors in patients with recurrent or relapsed lymphoma. Am J Hematol 2009; 84: 335-337.

51 Tricot G, Jagannath S, Vesole D, Nelson J, Tindle S, Miller L et al. Peripheral blood stem cell transplants for multiple myeloma: identification of favorable variables for rapid engraftment in 225 patients. Blood 1995; 85: 588-596.

52 Ketterer N, Salles G, Moullet I, Dumontet C, ElJaafariCorbin A, Tremisi P et al. Factors associated with successful mobilization of peripheral blood progenitor cells in 200 patients with lymphoid malignancies. Br J Haematol 1998; 103: $235-242$.

53 Koenigsmann M, Jentsch-Ullrich K, Mohren M, Becker E, Heim M, Franke A. The role of diagnosis in patients failing peripheral blood progenitor cell mobilization. Transfusion 2004; 44: 777-784.

54 Jantunen E, Itälä M, Siitonen T, Kuittinen T, Heiskanen J, Koivunen E et al. Blood stem cell mobilization and collection in patients with chronic lymphocytic leukaemia: a nationwide analysis. Bone Marrow Transplant 2008; 41: 239-244.

55 Perry AR, Watts MJ, Peniket AH, Goldstone AH, Linch DC. Progenitor cell yields are frequently poor in patients with histologically indolent lymphomas especially when mobilized within 6 months of previous chemotherapy. Bone Marrow Transplant 1998; 21: 1201-1205.

56 Moskowitz CH, Glassman JR, Wuest D, Maslak P, Reich L, Gucciardo A et al. Factors affecting mobilization of peripheral blood progenitor cells in patients with lymphoma. Clin Cancer Res 1998; 4: 311-316.

57 Demirer T, Buckner CD, Gooley T, Appelbaum FR, Rowley $\mathrm{S}$, Chauncey $\mathrm{T}$ et al. Factors influencing collection of peripheral blood stem cells in patients with multiple myeloma. Bone Marrow Transplant 1996; 17: 937-941.

58 Micallef I, Apostolidis J, Rohatiner A, Wiggins C, Crawley CR, Foran JM et al. Factors which predict unsuccessful mobilisation of peripheral blood progenitor cells following GCSF alone in patients with non-Hodgkin's lymphoma. Hematol J 2002; 1: 367-373.

59 Tarella C, Zallio F, Caracciolo D, Cherasco C, Bondesan P, Gavarotti $\mathrm{P}$ et al. Hematopoietic progenitor cell mobilization and harvest following an intensive chemotherapy debulking in indolent lymphoma patients. Stem Cells 1999; 17: 55-61.

60 Desikan KR, Tricot G, Munshi NC, Anaissie E, Spoon D, Fassas A et al. Preceding chemotherapy, tumour load and age influence engraftment in multiple myeloma patients mobilized with granulocyte colony-stimulating factor alone. $\mathrm{Br} J$ Haematol 2001; 112: 242-247.

61 Kuittinen T, Nousiainen T, Halonen P, Mahlamäki E, Jantunen E. Prediction of mobilisation failure in patients with non-Hodgkin's lymphoma. Bone Marrow Transplant 2004; 33: 907-912.

62 Mendrone Jr A, Arrais CA, Saboya R, Chamone Dde A, Dulley FL. Factors affecting hematopoietic progenitor cell mobilization: an analysis of 307 patients. Transfus Apher Sci 2008; 39: 187-192.

63 Canales MA, Fernandez-Jimenez MC, Martin A, Arrieta R, Caballero MD, Diez $\mathbf{J}$ et al. Identification of factors associated with poor peripheral blood progenitor cell mobilization in Hodgkin's disease. Haematologica 2001; 86: 494-498.

64 Hosing C, Saliba RM, Okoroji GJ, Popat U, Couriel D, Ali T et al. High-dose chemotherapy and autologous hematopoietic progenitor cell transplantation for non-Hodgkin's lymphoma in patients $>65$ years of age. Ann Oncol 2008; 19: 1166-1171.

65 de la Rubia J, Blade J, Lahuerta JJ, Ribera JM, Martinez R, Alegre A et al. Effect of chemotherapy with alkylating agents on the yield of $\mathrm{CD} 34+$ cells in patients with multiple myeloma. Results of the Spanish Myeloma Group (GEM) Study. Haematologica 2006; 91: 621-627.

66 Morris CL, Siegel E, Barlogie B, Cottler-Fox M, Lin P, Fassas A et al. Mobilization of $\mathrm{CD} 34+$ cells in elderly patients $(>/=70$ years) with multiple myeloma: influence of age, prior therapy, platelet count and mobilization regimen. Br J Haematol 2003; 120: 413-423.

67 Boccadoro M, Palumbo A, Bringhen S, Merletti F, Ciccone $\mathrm{G}$, Richiardi L et al. Oral melphalan at diagnosis hampers adequate collection of peripheral blood progenitor cells in multiple myeloma. Haematologica 2002; 87: 846-850.

68 Haas R, Mohle R, Fruhauf S, Goldschmidt H, Witt B, Flentje $\mathrm{M}$ et al. Patient characteristic associated with successful mobilizing and autografting of peripheral blood progenitor cells in malignant lymphoma. Blood 1994; 83: 3787-3794.

69 Jantunen E, Kuittinen T, Nousiainen T. Is chemotherapy scoring useful to predict progenitor cell mobilisation in patients with non-Hodgkin's lymphoma? Bone Marrow Transplant 2003; 32: 569-573.

70 Tarella C, Caracciolo D, Gavarotti P, Bondesan P, Cherasco $\mathrm{C}$, Omedè $\mathrm{P}$ et al. Circulating progenitors following high-dose sequential (HDS) chemotherapy with G-CSF: short intervals between drug courses severely impair progenitor mobilization. Bone Marrow Transplant 1995; 16: 223.

71 Rinn JP, Schwella N, Wollmer E, Jaques G, HeinzelGutenbrunner M, Strassmann G et al. Local irradiation prior to stem cell harvest has no influence on CD34 + yield: a quantitative analysis. Ann Hematol 2006; 85: 38-44.

72 Jansen J, Thompson J, Dugan M, Wiemann M, Hanks S, Greenspan A et al. Impaired PBPC collection in patients with myeloma after high-dose melphalan. Cytotherapy 2004; 6: 498-504.

73 Popat U, Saliba R, Thandi R, Hosing C, Qazilbash M, Anderlini $\mathrm{P}$ et al. Impairment of filgrastim-induced stem cell 
mobilization after prior lenalidomide in patients with multiple myeloma. Biol Blood Marrow Transplant 2009; 15: 718-723.

74 Kumar S, Dispenzieri A, Lacy MQ, Hayman SR, Buadi FK, Gastineau DA et al. Impact of lenalidomide therapy on stem cell mobilization and engraftment post-peripheral blood stem cell transplantation in patients with newly diagnosed myeloma. Leukemia 2007; 21: 2035-2042.

75 Mazumder A, Kaufman J, Niesvizky R, Lonial S, Vesole D, Jagannath S. Effect of lenalidomide therapy on mobilization of peripheral blood stem cells in previously untreated multiple myeloma patients. Leukemia 2008; 22: 1280-1281; author reply $1281-2$

76 Paripati H, Stewart AK, Cabou S, Dueck A, Zepeda VJ, Pirooz $\mathrm{N}$ et al. Compromised stem cell mobilization following induction therapy with lenalidomide in myeloma. Leukemia 2008; 22: 1282-1284.

77 Lysak D, Koza V, Steinerova K, Jindra P, Vozobulova V, Schutzova M. Mobilization of peripheral blood stem cells in CLL patients after front-line fludarabine treatment. Ann Hematol 2005; 84: 456-461.

78 Eve HE, Seymour JF, Rule SA. Impairment of peripheral blood stem-cell mobilisation in patients with mantle-cell lymphoma following primary treatment with fludarabine and cyclophosphamide \pm rituximab. Leuk Lymphoma 2009; 50: 463-465.

79 Tournilhac O, Cazin B, Leprètre S, Diviné M, Maloum K, Delmer A et al. Impact of frontline fludarabine and cyclophosphamide combined treatment on peripheral blood stem cell mobilization in B-cell chronic lymphocytic leukemia. Blood 2004; 103: 363-365.

80 Laszlo D, Galieni P, Raspadori D, Tozzi M, Lauria F, Martinelli G. Fludarabine combination regimen severely affected peripheral blood stem cell mobilization. Acta Haematol 2004; 111: 228-229.

81 Montillo M, Tedeschi A, Rossi V, Cairoli R, Pungolino E, Intropido $\mathrm{L}$ et al. Successful CD34+ cell mobilization by intermediate-dose Ara-C in chronic lymphocytic leukemia patients treated with sequential fludarabine and Campath1H. Leukemia 2004; 18: 57-62.

82 Michallet M, Thiebaut A, Dreger P, Remes K, Milpied N, Santini G et al. Peripheral blood stem cell (PBSC) mobilization and transplantation after fludarabine therapy in chronic lymphocytic leukaemia (CLL): a report of the European Blood and Marrow Transplantation (EBMT) CLL subcommittee on behalf of the EBMT Chronic Leukaemias Working Party (CLWP). Br J Haematol 2000; 108: 595-601.

83 Fruehauf S, Haas R, Conradt C, Murea S, Witt B, Mohle R et al. Peripheral blood progenitor cell (PBPC) counts during steady-state hematopoiesis allow to estimate the yield of mobilized PBPC after filgrastim (R-metHuG-CSF)-supported cytotoxic chemotherapy. Blood 1995; 85: 2619-2626.

84 Fruehauf S, Schmitt K, Veldwijk MR, Topaly J, Benner A, Zeller WJ et al. Peripheral blood progenitor cell (PBPC) counts during steady-state haemopoiesis enable the estimation of the yield of mobilized PBPC after granulocyte colony-stimulating factor supported cytotoxic chemotherapy: an update on 100 patients. Br J Haematol 1999; 105: 786-794.

85 Zimmerman TM, Michelson GC, Mick R, Grinblatt DL, Williams SF. Timing of platelet recovery is associated with adequacy of leukapheresis product yield after cyclophosphamide and G-CSF in patients with lymphoma. $J$ Clin Apher 1999; 14: 31-34.

86 Passos-Coelho JL, Braine HG, Davis JM, Huelskamp AM, Schepers KG, Ohly K et al. Predictive factors for peripheralblood progenitor-cell collections using a single large-volume leukapheresis after cyclophosphamide and granulocyte- macrophage colony-stimulating factor mobilization. $J$ Clin Oncol 1995; 13: 705-714.

87 Elliott C, Samson DM, Armitage S, Lyttelton MP, McGuigan D, Hargreaves R et al. When to harvest peripheral-blood stem cells after mobilization therapy: prediction of CD34positive cell yield by preceding day CD34-positive concentration in peripheral blood. J Clin Oncol 1996; 14: 970-973.

88 Basquiera AL, Abichain P, Damonte JC, Ricchi B, Sturich AG, Palazzo ED et al. The number of CD34(+) cells in peripheral blood as a predictor of the CD34 $(+)$ yield in patients going to autologous stem cell transplantation. $J$ Clin Apher 2006; 21: 92-95.

89 Kessinger A, Sharp JG. The whys and hows of hematopoietic progenitor and stem cell mobilization. Bone Marrow Transplant 2003; 31: 319-329.

90 Perez-Simon JA, Martin A, Caballero D, Corral M, Nieto MJ, Gonzalez M et al. Clinical significance of CD34 + cell dose in long-term engraftment following autologous peripheral blood stem cell transplantation. Bone Marrow Transplant 1999; 24: 1279-1283.

91 Ashihara E, Shimazaki C, Okano A, Hatsuse M, Okamoto A, Shimura K et al. Infusion of a high number of CD34+ cells provides a rapid hematopoietic recovery and cost savings in autologous peripheral blood stem cell transplantation. Jpn J Clin Oncol 2002; 32: 135-139.

92 Gunn N, Damon L, Varosy P, Navarro W, Martin T, Ries C et al. High CD34 + cell dose promotes faster platelet recovery after autologous stem cell transplantation for acute myeloid leukemia. Biol Blood Marrow Transplant 2003; 9: 643-648.

93 Scheid C, Draube A, Reiser M, Schulz A, Chemnitz J, Nelles $\mathrm{S}$ et al. Using at least $5 \times 10(6) / \mathrm{kg} \mathrm{CD} 34+$ cells for autologous stem cell transplantation significantly reduces febrile complications and use of antibiotics after transplantation. Bone Marrow Transplant 1999; 23: 1177-1181.

94 Siena S, Schiavo R, Pedrazzoli P, Carlo-Stella C. Therapeutic relevance of CD34 cell dose in blood cell transplantation for cancer therapy. J Clin Oncol 2000; 18: 1360-1377.

95 Bolwell BJ, Pohlman B, Rybicki L, Sobecks R, Dean R, Curtis $\mathbf{J}$ et al. Patients mobilizing large numbers of CD34+ cells ('super mobilizers') have improved survival in autologous stem cell transplantation for lymphoid malignancies. Bone Marrow Transplant 2007; 40: 437-441.

96 Gordan LN, Sugrue MW, Lynch JW, Williams KD, Khan SA, Wingard JR et al. Poor mobilization of peripheral blood stem cells is a risk factor for worse outcome in lymphoma patients undergoing autologous stem cell transplantation. Leuk Lymphoma 2003; 44: 815-820.

97 O'Shea D, Giles C, Terpos E, Perz J, Politou M, Sana V et al. Predictive factors for survival in myeloma patients who undergo autologous stem cell transplantation: a single-centre experience in 211 patients. Bone Marrow Transplant 2006; 37: 731-737.

98 Pavone V, Gaudio F, Console G, Vitolo U, Iacopino P, Guarini A et al. Poor mobilization is an independent prognostic factor in patients with malignant lymphomas treated by peripheral blood stem cell transplantation. Bone Marrow Transplant 2006; 37: 719-724.

99 Toor AA, Ayers J, Strupeck J, Parthasarathy M, Creech S, Rodriguez $\mathrm{T}$ et al. Favourable results with a single autologous stem cell transplant following conditioning with busulphan and cyclophosphamide in patients with multiple myeloma. Br J Haematol 2004; 124: 769-776.

100 Yoon DH, Sohn BS, Jang G, Kim EK, Kang BW, Kim C et al. Higher infused CD34+ hematopoietic stem cell dose correlates with earlier lymphocyte recovery and better clinical outcome after autologous stem cell transplantation in non-Hodgkin's lymphoma. Transfusion 2009; 49: 1890-1900. 
101 Breems DA, van Hennik PB, Kusadasi N, Boudewijn A, Cornelissen JJ, Sonneveld $\mathrm{P}$ et al. Individual stem cell quality in leukapheresis products is related to the number of mobilized stem cells. Blood 1996; 87: 5370-5378.

102 Lanza F, Campioni D, Moretti S, Dominici M, Punturieri M, Focarile $\mathrm{E}$ et al. CD34(+) cell subsets and long-term culture colony-forming cells evaluated on both autologous and normal bone marrow stroma predict long-term hematopoietic engraftment in patients undergoing autologous peripheral blood stem cell transplantation. Exp Hematol 2001; 29: 1484-1493.

103 Siena S, Bregni M, Brando B, Belli N, Ravagnani F, Gandola L et al. Flow cytometry for clinical estimation of circulating hematopoietic progenitors for autologous transplantation in cancer patients. Blood 1991; 77: 400-409.

104 Schulman KA, Birch R, Zhen B, Pania N, Weaver CH. Effect of CD34 $(+)$ cell dose on resource utilization in patients after high-dose chemotherapy with peripheral-blood stem-cell support. J Clin Oncol 1999; 17: 1227.

105 Jantunen E, Kuittinen T. Blood stem cell mobilization and collection in patients with lymphoproliferative diseases: practical issues. Eur J Haematol 2008; 80: 287-295.

106 Goterris R, Hernandez-Boluda JC, Teruel A, Gomez C, Lis $\mathrm{MJ}$, Terol MJ et al. Impact of different strategies of secondline stem cell harvest on the outcome of autologous transplantation in poor peripheral blood stem cell mobilizers. Bone Marrow Transplant 2005; 36: 847-853.

107 Gazitt Y, Freytes CO, Callander N, Tsai TW, Alsina M, Anderson $\mathbf{J}$ et al. Successful PBSC mobilization with highdose G-CSF for patients failing a first round of mobilization. J Hematother 1999; 8: 173-183.

108 Zeller W, Gutensohn K, Stockschlader M, Dierlamm J, Kroger N, Koehne G et al. Increase of mobilized CD34positive peripheral blood progenitor cells in patients with Hodgkin's disease, non-Hodgkin's lymphoma, and cancer of the testis. Bone Marrow Transplant 1996; 17: 709-713.

109 Sheridan WP, Begley CG, To LB, Grigg A, Szer J, Maher D et al. Phase II study of autologous filgrastim (G-CSF)mobilized peripheral blood progenitor cells to restore hemopoiesis after high-dose chemotherapy for lymphoid malignancies. Bone Marrow Transplant 1994; 14: 105-111.

110 Spitzer G, Adkins D, Mathews M, Velasquez W, Bowers C, Dunphy $\mathrm{F}$ et al. Randomized comparison of G-CSF + GMCSF vs G-CSF alone for mobilization of peripheral blood stem cells: effects on hematopoietic recovery after high-dose chemotherapy. Bone Marrow Transplant 1997; 20: 921-930.

111 Gianni AM, Siena S, Bregni M, Tarella C, Stern AC, Pileri A et al. Granulocyte-macrophage colony-stimulating factor to harvest circulating haemopoietic stem cells for autotransplantation. Lancet 1989; 2: 580-585.

112 Cavo M, Zamagni E, Tosi P, Tacchetti P, Cellini C, Cangini $\mathrm{D}$ et al. Superiority of thalidomide and dexamethasone over vincristine-doxorubicindexamethasone (VAD) as primary therapy in preparation for autologous transplantation for multiple myeloma. Blood 2005; 106: 35-39.
113 Ladetto M, De Marco F, Benedetti F, Vitolo U, Patti C, Rambaldi A et al. Prospective, multicenter randomized GITMO/IIL trial comparing intensive (R-HDS) versus conventional (CHOP-R) chemoimmunotherapy in high-risk follicular lymphoma at diagnosis: the superior disease control of R-HDS does not translate into an overall survival advantage. Blood 2008; 111: 4004-4013.

114 Olivieri A, Brunori M, Capelli D, Montanari M, Massidda D, Gini $\mathrm{G}$ et al. therapy with an outpatient DHAP schedule followed by PBSC transplantation in 79 lymphoma patients: an intention to mobilize and transplant analysis. Eur $J$ Haematol 2004; 72: 10-17.

115 Breitkreutz I, Lokhorst HM, Raab MS, Holt B, Cremer FW, Herrmann $\mathrm{D}$ et al. Thalidomide in newly diagnosed multiple myeloma: influence of thalidomide treatment on peripheral blood stem cell collection yield. Leukemia 2007; 21: 1294-1299.

116 Moog R. Management strategies for poor peripheral blood stem cell mobilization. Transfus Apher Sci 2008; 38: 229-236.

117 Pastore D, Specchia G, Mestice A, Liso A, Pannunzio A, Carluccio $\mathrm{P}$ et al. Good and poor CD $34+$ cells mobilization in acute leukemia: analysis of factors affecting the yield of progenitor cells. Bone Marrow Transplant 2004; 33: 1083-1087.

118 Calandra G, McCarty J, McGuirk J, Tricot G, Crocker SA, Badel $\mathrm{K}$ et al. AMD3100 plus G-CSF can successfully mobilize CD34+ cells from non-Hodgkin's lymphoma, Hodgkin's disease and multiple myeloma patients previously failing mobilization with chemotherapy and/or cytokine treatment: compassionate use data. Bone Marrow Transplant 2008; 41: 331-338.

119 Giralt S, Stadtmauer EA, Harousseau JL, Palumbo A, Bensinger $\mathrm{W}$, Comenzo RL et al. International myeloma working group (IMWG) consensus statement and guidelines regarding the current status of stem cell collection and highdose therapy for multiple myeloma and the role of plerixafor (AMD 3100). Leukemia 2009; 23: 1904-1912.

120 Fowler CJ, Dunn A, Hayes-Lattin B, Hansen K, Hansen L, Lanier $\mathrm{K}$ et al. Rescue from failed growth factor and/or chemotherapy HSC mobilization with G-CSF and plerixafor (AMD3100): an institutional experience. Bone Marrow Transplant 2009; 43: 909-917.

121 Micallef IN, Stiff PJ, DiPersio JF, Maziarz RT, McCarty JM, Bridger $\mathrm{G}$ et al. Successful stem cell remobilization using plerixafor (mozobil) plus granulocyte colony-stimulating factor in patients with non-Hodgkin lymphoma: results from the plerixafor NHL phase 3 study rescue protocol. Biol Blood Marrow Transplant 2009; 15: 1578-1586.

This work is licensed under the Creative Commons Attribution-NonCommercial-No Derivative Works 3.0 Unported License. To view a copy of this license, visit http://creativecommons.org/licenses/by-nc-nd/3.0/ 